Jagannathan, M., Kamma, R. C., Renganaidu, V. and Ramalingam, S. (2018). "Enablers for Sustainable Lean Construction in India." In: Proc. $26^{\text {th }}$ Annual Conference of the International. Group for Lean Construction (IGLC), González, V.A. (ed.), Chennai, India, pp. 910-922. DOI: doi.org/10.24928/2018/0247. Available at: www.iglc.net.

\title{
ENABLERS FOR SUSTAINABLE LEAN CONSTRUCTION IN INDIA
}

\author{
Murali Jagannathan ${ }^{1}$, Ravindranadh Chowdary Kamma ${ }^{2}$, \\ Venkatesan Renganaidu ${ }^{3}$, Shobha Ramalingam ${ }^{4}$
}

\begin{abstract}
Sustainability and Lean practices are two modern philosophies that are wielding influence in the construction industry. Researchers have observed that Sustainability and Lean implementation go hand in hand and there are benefits in implementing them together as 'Sustainable Lean Construction' (SLC). However, it was observed through a literature review that the contractors' top management support for implementing sustainable practices was not as evident as that of Lean implementation. In the Indian construction scenario, with the Sustainability initiatives and Lean implementation in preliminary stages, time is ripe for viewing them as concepts that complement each other and look for its widespread application as a combined credo. Commitment by owner organizations, compatibility with an existing contractual framework, design ability, constructability, government policy support, financial attractiveness, long-term relationship and increased market penetration are among the enablers that support the implementation of SLC in Indian conditions. The identified enablers and action points, therefore, pave the way for achieving the benefits of lean implementation and sustainable construction practices for fostering SLC practices in Indian construction.
\end{abstract}

\section{KEYWORDS}

Sustainability, Lean, Construction, Sustainable Lean Construction, Organizations, Enablers

\section{INTRODUCTION}

The word Sustainability means "to meet the needs of the present without compromising the ability of future generations to meet their own needs" as articulated by The World Commission on Environment and Development (WCED1987). Sustainability has greater relevance in the construction industry owing to the nature of operations involved. Approaches like 'triple bottom line', help in viewing sustainability through the lens of the

\footnotetext{
Assistant Professor, NICMAR Pune, India, +91 9663410101, mjagannathan@ nicmar.ac.in Assistant Professor, NICMAR Hyderabad, India, +91 9038645481, kravindranadh@ nicmar.ac.in Professor, NICMAR Hyderabad, India, +91 9444091973, rvenkatesan@nicmar.ac.in Assistant Professor, NICMAR Pune, India,+91 02066859122, sramalingam@nicmar.ac.in
} 
environment, economics, and social relevance. Sustainable solutions in construction aim at processes that have minimal or no detrimental impact on ecological and social systems.

With reference to Lean Construction (LC), the universal view is value addition and waste reduction (Koskela 1992). In other words, lean concepts emphasize that non-value adding activities consume resources, and therefore are wasteful and not economically sustainable over the long run. Without waste reduction, and subsequently elimination, processes, and operations are less likely to be sustainable.

The Construction industry, particularly in India, is facing twin problems. The first problem is about the detrimental effect on people, society and the environment (sustainability issues) and the second being the decreased financial attractiveness of the business. The concepts of Sustainable Construction (SC) and Lean Construction (LC) are, in the opinion of the authors, well designed to address the twin problems facing the Industry in Indian conditions. Generally, SC and LC are viewed as management frameworks that can independently provide solutions to manage the sustainability issues and provide financial incentives (through waste reduction and value addition) respectively. Research has shown that SC and LC mutually reinforce each other and there is a synergistic output that can be achieved by considering them as a combined credo (Salvatierra-Garrido and Pasquire 2011; Vieira and Cachadinha 2011; Bae and Kim 2007; Campos et al. 2012; Carneiro et al. 2012; Holloway and Parrish 2013; Johnsen and Drevland 2016; Novak 2012). While this concept is existent, there are limited studies to understand the enablers for the same in the Indian context.

Adoption of sustainable practices is still considered a part of the mandatory 'Corporate Social Responsibility' (CSR) initiative. It has unfortunately not entered into the mainstream focus of construction businesses (Holloway and Parrish 2013). Assuming that there is a valid need for implementing sustainable practices in Indian construction industry, the long-term research objective is to develop means to bring sustainability in the mainstream focus of Indian construction organizations. The authors strongly believe that the required focus is achievable through the implementation of sustainable practices as a Lean concept rather than as a standalone concept. As a first step, the authors validate the assumptions as stated above through a review of existing literature. Subsequently, the 'enablers' that would help to implement 'Lean focused - SC' in Indian construction industry are conceptually identified with its perceived potential to eliminate wastes.

\section{METHODOLOGY}

In the initial sections of the paper, existing literature is reviewed to understand the extent of top management support for the implementation of Lean methods and sustainable practices in the construction sector in India. The importance of adoption of sustainable practices in the Indian context and the urgency for the same is established in the subsequent section. It is then followed by a review of existing literature on Sustainable Lean Construction (SLC). The authors then conceptually identify the enablers of SLC that help in its implementation in the Indian context. 
Murali Jagannathan, Ravindranadh Chowdary Kamma, Venkatesan Renganaidu,

\section{LITERATURE REVIEW}

\section{IMPLEMENTING LEAN PRACTICES IN INDIAN CONSTRUCTION INDUSTRY}

Over the years, there is an increased interest in the adoption of lean practices by the Indian construction organizations. In the recently concluded Indian Lean Construction Conference (ILCC 2017), held at Chennai, India, it was heartening to note that the construction industry in India had embraced lean practices and documented success stories. Raghavan (2017) notes that, even though the lean awareness in India is low, there are very good indicators indicating growing inclination towards Lean. Lean techniques like Last Planner System (LPS), and Location-Based Management System (LBMS), when implemented at project sites, resulted in improved cycle time, reduced instances of delays and enhancing coordination and communication among various stakeholders (Vaidyanathan et al. 2016). Mathew (2017), in the study on lean implementation ina building construction project, observed improved resource utilization, waste minimization among others.

It is seen from the existing literature that is specific to Indian construction companies that top management is actively involved in adopting Lean practices that can make a difference to their bottom line.The Table 1 below tabulates the adoption of Lean practices by Indian construction organizations in papers that were published in 2017 alone.

Table 1: Papers on Lean implementation in Indian construction industries

\begin{tabular}{|c|c|c|c|}
\hline Sl.No. & Organization & $\begin{array}{l}\text { ILCC } 2017 \text { Conference } \\
\text { paper author(s) }\end{array}$ & Lean Methods adopted \\
\hline 1 & Godrej Construction & $\begin{array}{l}\text { Mathew } 2017 \\
\text { Bhandarkar and Sawant } 2017 \\
\text { Lahoti and Rathore } 2017\end{array}$ & $\begin{array}{l}\text { Kaizen, 5S, Total Project } \\
\text { Management, Value Stream } \\
\text { Mapping (VSM), Last Planner } \\
\text { System }\end{array}$ \\
\hline 2 & L\&T Construction & $\begin{array}{l}\text { Kumar and Prabhakaran } \\
2017\end{array}$ & $\begin{array}{l}\text { Autodesk BIM } 360 \text { to digitize } \\
\text { and optimized workflows }\end{array}$ \\
\hline 3 & Tata Projects & $\begin{array}{l}\text { Danthi et al. } 2017 \\
\text { Murthy et al. } 2017\end{array}$ & VSM \\
\hline 4 & $\begin{array}{l}\text { Maha Metro Rail } \\
\text { Corporation Limited }\end{array}$ & Dhopte 2017 & $\begin{array}{l}\text { Enterprise Resource Planning \& } \\
\text { 5D BIM }\end{array}$ \\
\hline 5 & $\begin{array}{l}\text { AFCONS Infrastructure } \\
\text { Limited }\end{array}$ & $\begin{array}{l}\text { Giridhar et al. } 2017 \\
\text { Lad et al. } 2017\end{array}$ & $\begin{array}{l}\text { Knowledge management as an } \\
\text { enabler of building a lean culture }\end{array}$ \\
\hline 6 & Godrej Properties & Potdar et al. 2017 & Collaborative planning and VSM \\
\hline 7 & $\begin{array}{l}\text { Tata Realty and } \\
\text { Infrastructure Limited }\end{array}$ & Patil et al. 2017 & \\
\hline
\end{tabular}

\section{SUSTAINABLE PRACTICES IN INDIAN CONSTRUCTION INDUSTRY}

Traditional Indian architecture incorporates the concept of sustainability in its very design. However, with the growth in the construction complexity and the influence of 
modern day practices, there is a need to bring back the focus on sustainable construction (Arif et al. 2009). Unlike adoption of Lean practices, the primary thrust to adopt Sustainable methods is provided by the regulatory agencies of the government and the owner organizations that are willing to implement green practices (Shen et al. 2006; Arif et al. 2009; Holloway and Parrish 2013; Liang et al. 2014). It is observed by researchers that the commitment of top management provides a significant impetus towards the adoption of sustainable construction practices (Tan et al. 2011; Athapaththu and Karunasena 2017).

In summary, the commitment of the top management of Indian construction organizations in the adoption of sustainable technologies is more due to external pressure than an internal requirement and therefore, the initiatives that are taken are mostly to ensure the minimum compliance requirement (Arif et al. 2009).

\section{SUSTAINABLE PRACTICES IN INDIAN CONSTRUCTION INDUSTRY - ESTABLISHING THE URGENCY}

Gort (2008) observes that sustainability is looked upon as a 'nuisance,' and companies are not incentivized to fully engage as sustainable practices are still considered to be an additional cost, not delivering profits in the short-term. To establish the urgency and relevance of implementing sustainable practices in the Indian construction sector, the authors have adopted the 'dimensions of sustainability' framework identified presented by Piercy and Brammer (2012) (as quoted by Piercy and Rich 2015). Piercy and Brammer (2012) (as quoted by Piercy and Rich 2015) observed that sustainability had six dimensions that include "environment, workforce, supply chain, community, governance, and quality issues". In addition, the authors have identified an additional dimension 'Contractual Arrangement' that is observed to impact sustainable practices. Dimension D1 to Dimension D7 is the sustainability dimensions described below:

\section{D1 - Environment}

The detrimental impact on the environment due to the construction industry is considered to be more severe in developing countries than in developed countries due to the volume of work and practices that are not sustainable (du Plessis 2002). It has been observed that the two major raw materials of construction, cement, and steel, alone are accountable for a large quantum of greenhouse gas emissions (du Plessis 2002). The problems of deforestation, soil erosion, groundwater pollution, health deterioration, unscientific landfills are closely associated with construction in the Indian context too. Sustainable practices are hence in need to protect the environment from further decline.

\section{D2 -Workforce}

Developing countries like India, which has still not reached the levels of automation practiced in the developed economies, rely heavily on the manual workforce for construction activities. India is already facing a shortage of quality workforce supply (Loganathan and Kalidindi 2016) for the construction sector, and the situation is bound to worsen if there is no immediate action for improvement. To compound the availability issue, a study by Patel and Jha (2016) estimated that there are around "38 fatal accidents 
Murali Jagannathan, Ravindranadh Chowdary Kamma, Venkatesan Renganaidu, Shobha Ramalingam

per day in the Indian construction sector" and categorized the building industry as the second most hazardous sector in India. Women workers in the unskilled category face routine difficulties that include wage discrimination, harassment and poor working conditions (Devi and Kiran2013; Anvekar and R 2015). The available workforce is not trained for the right skills and quality (Loganathan and Kalidindi 2017). As a profession, the construction industry has become unattractive (du Plessis 2002), rising questions on the future of the livelihood of millions of people who are associated either directly or indirectly with the sector. Hence, there is an immediate need for sustainable practices in this domain without which the future of the sector is bleak with a short supply of quality workforce.

\section{D3 - Supply Chain}

Piercy and Rich (2015)noted that supply chain sustainability should be achieved not only in material sourcing but also in labour management, ethical trade practices, on-time payment and supportive behavior. The construction industry remains highly fragmented with over 95\% of the enterprises employing less than 200 persons (Planning Commission 2013) and mostly unorganized. Highly sophisticated and non-linear supply chains (Negi et al. 2017) serve these enterprises, resulting in the accumulation of the unsustainable practices in almost every level. Therefore, it is not only urgent but also a herculean task to bring sustainable practices across construction supply chains. The policy intervention and Government support are critical in this domain.

\section{D4 - Community}

Construction activities have a profound impact on communities. Organizations relate themselves to communities through activities as part of corporate social responsibilities (CSR). CSR is also now a part of mandatory sustainable initiatives to be demonstrated by organizations with atleast Indian Rupees (INR) 5 Crore net profits or INR 1000 Crore turnover or INR 500 crore net worth (Indian Express 2014). With over 95\% of the construction organizations employing less than 200 persons (Planning Commission 2013) and not falling under the CSR criteria described above, the effectiveness of the CSR initiatives may not be significant.

\section{D5 - Governance}

Piercy and Rich (2015), define governance (in this context) as 'transparency in corporate governance and legal compliance with clear and written ethics policy and communication channels'. Kardos (2012) opines that good governance may not assure sustainable development, but its absence impedes it. The Organization for Economic Co-operation and Development (OECD) Principles (2004) elucidates that an "effective corporate governance system within the company and across the economy helps in creating efficient markets" which in turn lowers the cost of capital, supporting efficient use of resources (Kocmanova 2011). Mukherjee and Ghosh (2003) observed that corporate governance in India was in 'a nascent stage'. Pande and Kaushik (2013) have noted that the business management structure in India is entirely different (due to the constant conflict between the majority and minority shareholders) from other developed countries 
and that the existing corporate governance framework does not adequately address this uniqueness.

\section{D6 - Quality Issues}

Achieving the product and service quality (Piercy and Rich 2015) by meeting or exceeding the customer expectations is perhaps at the center of any philosophy or a framework, including sustainability. Organizations whose products and services have not fulfilled the minimum customer requirements have not sustained for long. Though there has been significant progress in the product quality, in the opinion of the authors, the service quality in construction needs critical improvement. In their study, Jha and Iyer (2006) identified the following factors that adversely affect the quality performances of Indian construction projects are: "conflict among project participants; hostile socioeconomic environment; harsh climatic condition; project manager's ignorance and lack of knowledge; and aggressive competition during tendering." These quality issues need to be addressed for sustainable construction.

\section{D7 - Additional Dimension - Contractual Arrangement}

In addition to the six dimensions identified by Piercy and Brammer (2012) (as quoted by Piercy and Rich 2015), the seventh dimension that needs sustainable practices in place is the 'contractual arrangement'.' Contractual practices continue to be transactional rather than relational. From authors' point of view, the transactional contracts have primarily resulted in growing mistrust and disputes affecting the sustainability of construction business.

In summary, the discussion above shows an urgent need to implement sustainable practices in the Indian construction industry, failing which, without quality resources and favorable environment, there will be irreparable damage caused to the future of the industry. However, the urgency required in implementation has not translated into action due to lack of top management commitment in implementing sustainable practices.

\section{ACHIEVING SUSTAINABLE LEAN CONSTRUCTION IN INDIA}

Several authors have noted the benefit of integrating Lean and Sustainable practices (e.g. Huovila and Koskela 1998; Lapinski et al. 2006, Ogunbiyi et al. 2014, SalvatierraGarrido and Pasquire 2011; Rueff and Cachadinha 2011; Bae and Kim 2007; Campos et al. 2012; Carneiro et al. 2012; Holloway and Parrish 2013; Johnsen and Drevland 2016; Novak 2012; Marhani et al. 2013; Jamil and Fathi 2016; Dixit et al. 2017). Gort (2008) discusses SLC in the context of manufacturing industry. Fliedner and Majeske (2010) presented on how sustainability can help in adding economic value to an organization with illustrations from across sectors. Salem et al. (2014) explained how Lean practices helped in reducing the impact of construction on environmental, economic and social aspects of the pavement construction projects.

In summary, SLC helps the organization to expand its thinking beyond the organizational boundaries, while LC focuses within the organization (Fliedner and Majeske 2010). However, it is noted that the research focus in the area of SLC has been limitedto understand how Lean concepts and its tools reinforce primarily three 
Murali Jagannathan, Ravindranadh Chowdary Kamma, Venkatesan Renganaidu,

Shobha Ramalingam

dimensions of sustainability, namely, environment, social and economic development. In this paper, the authors therefore consider it essential to integrate Lean principles with sixdimensional Sustainability framework proposed by Piercy and Brammer (2012) along with the additional dimension on 'contractual agreement' in the Indian context and in doing so, identify a set of enablers that would enhance SLC implementation. By demonstrating the possibility of Lean benefits through Sustainable practices, the authors expect to find greater support for the implementation of SLC from the top management.

\section{ENABLERS}

Lean and Sustainability are mutually supporting concepts, and with some incremental steps, it is possible to achieve the benefits of Lean implementation, through sustainable construction practices and thereby gain management commitment. Authors term these 'incremental steps' as enablers for SLC in the Indian context. The enablers identified below help in Lean implementation in addition to wielding a positive influence on all seven dimensions of sustainability. The enablers for SLC are described from E1 to E6 below based on the combined industry experience of the authors. While it is discussed how each Enabler enables incorporation of sustainable practices, its Lean impact (in the seven-dimensional framework)is illustrated in detail in one specific case in Table 2.

\section{E1 - OWNER COMMITMENT}

Committed owners ensure all the stakeholders in the supply chain commit to the requirements of sustainable construction. The commitment must be manifested suitably through the terms of Contract between the parties.

\section{E2 - DESIGNABILITY AND CONSTRUCTABILITY}

For the construction process to be sustainable, its design must be sustainable first. The project design must be in line with the end-user requirement. A conflict-free design is possible only with due consideration of designability and constructability aspects in the early stages of construction. In terms of Lean benefits, the enabler helps in the reduction of rework, waiting times and over-processing.

\section{E3 - GOVERNMENT POLICY}

Support by the Government in implementing sustainable practices would go a long way in nurturing sustainable practices in organizations. Mandatory reporting of CSR activities, corporate governance among others, are some of the steps in this direction. Government policy support in the form of incentives helps in reducing the resistance of organizations to make their practices sustainable (thereby automatically make their project sites Lean).

\section{E4 - LONG-TERM PARTNERSHIP}

Long-term partnerships are a result of trust. Such partnerships help in the faster adoption and smoother implementation of sustainable practices. Lean benefits include minimized learning curve impact, lesser attrition, the reduction of rework and waiting times, among others. 


\section{E5 - HIGH MARKET PENETRATION}

Organizations having high market penetration have considerable influence over their contractors/subcontractors, suppliers and vendors. In all such cases, implementation of sustainable practices across the supply chain is facilitated, enabling ts quicker adoption. The organizations down the line would have to fall in line with their influential customers (who are market leaders) failing which they have the risk of losing their businesses. High market penetration also implies the presence of greater acceptability amongst usercommunities. When organizations reciprocate through community-focused sustainable initiatives, the local support is further reinforced. The mutual support helps in reducing typical construction delays due to protests from local communities.

\section{E6 - COMPATIBILITY WITH EXISTING CONTRACTUAL FRAMEWORKS}

Construction projects in India, especially in the public sector are executed using standard contract formats. Owner organizations are typically hesitant to deviate from the existing formats. Introducing sustainable practices seamlessly within existing contract frameworks will receive greater acceptance amongst the stakeholders.

Table 2: Illustration of 'Owner Commitment' as an Enabler

\begin{tabular}{|c|c|c|}
\hline $\begin{array}{c}\text { Dimension of } \\
\text { Sustainability } \\
\text { (Piercy and } \\
\text { Brammer 2012) }\end{array}$ & Suggested Action Points & $\begin{array}{c}\text { Lean Impact that may motivate } \\
\text { organizations to adopt sustainable } \\
\text { practices }\end{array}$ \\
\hline Environment & $\begin{array}{l}\text { - Limits on allowable material wastage } \\
\text { with incentive/penalty system } \\
\text { - Store audits to ensure compliance with } \\
\text { acceptable preservation requirements }\end{array}$ & $\begin{array}{l}\text { - Reducing overproduction/ over- } \\
\text { processing }\end{array}$ \\
\hline Workforce & $\begin{array}{l}\text { Minimum facilities to be provided to } \\
\text { the workmen for their living, dining, } \\
\text { and recreation to ensure ethical } \\
\text { treatment } \\
\text { - Regular audits of labor camps } \\
\text { Safety audits to ensure workplace } \\
\text { safety requirement }\end{array}$ & $\begin{array}{l}\text { Improving worker morale and } \\
\text { reduction of attrition - } \\
\text { Reduction in waiting times due } \\
\text { to lost man-hours as a result of } \\
\text { accidents/injuries }\end{array}$ \\
\hline Supply chain & $\begin{array}{l}\text { Emphasis on long-term partnership } \\
\text { sub-contract agreements } \\
\text { - Vendor development, evaluation, and } \\
\text { training by main contractors }\end{array}$ & $\begin{array}{l}\text { - Reducing waiting times for } \\
\text { deliveries }\end{array}$ \\
\hline Community & $\begin{array}{l}\text { - Local community involvement } \\
\text { through part time/ full-time } \\
\text { employment opportunities } \\
\text { - CSR activities in association with } \\
\text { contractors and subcontractors }\end{array}$ & $\begin{array}{l}\text { Reducing travel time for } \\
\text { workmen transportation/ } \\
\text { reduction in dependence on } \\
\text { migrant workmen }\end{array}$ \\
\hline
\end{tabular}


Murali Jagannathan, Ravindranadh Chowdary Kamma, Venkatesan Renganaidu, Shobha Ramalingam

\begin{tabular}{lll}
\hline Governance & $\begin{array}{l}\text { A communication protocol, frequent } \\
\text { meetings, constructability workshops, } \\
\text { team-building exercises. }\end{array}$ & $\begin{array}{l}\text { Reduced waiting times for } \\
\text { instructions with clarity in } \\
\text { communication }\end{array}$ \\
& $\begin{array}{l}\text { Such processes would help in } \\
\text { contractor/ subcontract } \\
\text { organizations to internalize such } \\
\text { practices within their } \\
\text { organizations }\end{array}$ \\
Quality & $\begin{array}{l}\text { Process quality improvements through } \\
\text { KPI (Key Performance Indicator) } \\
\text { scoring for contractor's approach to } \\
\text { resolve issues and differences }\end{array}$ & $\begin{array}{l}\text { Minimized defects/waiting } \\
\text { times }\end{array}$ \\
Contractual & $\begin{array}{l}\text { promoting relational contracts that } \\
\text { work on the principle of risk and } \\
\text { reward sharing in a blame-free culture }\end{array}$ & $\begin{array}{l}\text { Reduction in waiting } \\
\text { time/delays/inventory pile-up }\end{array}$ \\
\hline
\end{tabular}

\section{CONCLUSION AND LIMITATION}

From the experience and understanding of the authors and the support of the existing literature, it is vivid beyond doubt that there is a need for an increased focus on implementing sustainable practices in Indian construction industry on an urgent basis. However, the urgency has not translated into concrete action because of the lack of contractor organization top management support. The absence of interest seems to stem from the fact that the construction organizations are more focused on the achievement of financial goals rather than environmental goals. Paradoxically, the efforts to bring in sustainability in construction require additional cost and time (Shen et al. 2006; Saggin et al. 2015) and the returns are realizable only in the long run (Tan et al. 2011), and hence management focus is lost. In the Indian construction domain, there seems to be an increased focus on adopting lean practices. Lean implementation has been receiving necessary top management support. Fortunately, Lean and Sustainability are mutually supporting concepts, and with some incremental steps, it is possible to achieve the benefits of lean implementation, through sustainable construction practices. These 'incremental steps' are termed as enablers for Sustainable Lean Construction in the Indian context.

The paper is purely conceptual and is not supported by any formal survey data. The authors have put down their view based on their experiences in discussion with some academic and industry professionals. The research can further be extended to validate the enablers listed out by the authors in construction projects through a survey or case study based research.

\section{REFERENCES}

Anvekar, S. R., and R, M. L. (2015). "Women Workers in Construction Industry: Issues and Challenges Relating Working Conditions in Bengaluru." Conference presentation, (January 2016). 
Arif, M., Egbu, C., Haleem, A., Kulonda, D., and Khalfan, M. (2009). "State of green construction in India: drivers and challenges." Journal of Engineering, Design and Technology, 7(2), 223-234.

Athapaththu, K. I., and Karunasena, G. (2018). "Framework for sustainable construction practices in Sri Lanka." Built Environment Project and Asset Management.

Bae, J. W. and Kim, Y. W. (2007). "Sustainable value on construction project and application of lean construction methods." Proc. of the $15^{\text {th }}$ Ann. Conf. of the Int'l Group for Lean Construction. East Lansing, Michigan, USA.

Bhandarkar, Ramesh, V., and Sawant, Priyant, K. (2017). "Lean integrated construction project."Proc., of the Indian Lean Construction Conference, Chennai, India, C41C52.

Campos, I. B., Oliveira, D. D., Carneiro, S., Carvalho, A. D., and Neto, J. (2012). "Relation between the sustainable maturity of construction companies and the philosophy of lean construction." Proc. of the $20^{\text {th }}$ Ann. Conf. of the Int'l Group for Lean Construction. San Diego, USA.

Carneiro, S. B., Campos, I. B., Oliveira, D. D., and Neto, J. P. B. (2012). "Lean and green: a relationship matrix."Proc. of the $20^{\text {th }}$ Ann. Conf. of the Int'l Group for Lean Construction. San Diego, USA.

Danthi, C., Parashuram, K., Sharma., R. M., and Prasad, M. B. (2017). "Productivity Improvement of PSC sleepers."Proc., of the Indian Lean Construction Conference, Chennai, India, C68 - C74.

Devi, K., and Kiran, U. V. (2013). "Status of female workers in construction industry in India: A review." International Journal of Humanities and Social Science, 14, 27-30.

Dhopte, S. (2017). "Case Study - 5D BIM Implementation for Metro Project."Proc., of the Indian Lean Construction Conference, Chennai, India, C75 - C81.

Dixit, S., Mandal, S. N., Sawhney, A., and Singh, S. (2017). "Area of linkage between lean construction and sustainability in Indian construction industry." International Journal of Civil Engineering \& Technology, 8(8), 623-636.

Du Plessis, C. (2002). Agenda 21 for: Sustainable construction in developing countries a discussion document.

Fliedner, G., and Majeske, K. (2010). "Sustainability: the new lean frontier." Production and Inventory Management Journal, 46(1), 6-13.

Giridhar, R., Gaikwad, D., and Lad, J. (2017). "Knowledge Management and its Application in Developing Lean Culture."Proc., of the Indian Lean Construction Conference, Chennai, India, C82 - C90.

Gort, R. E. (2008). "LEAN AND SUSTAINABILITY How Can They Reinforce Each Other?" MBA Management Project Report Management Project submitted to TiasNimbas Business School in accordance with the rules of Bradford University School of Management in partial fulfilment of the requirements for the degree of Master in Business Administration.

Holloway, S., and Parrish, K. (2013). "The contractor's self-perceived role in sustainable construction: Survey results." Proc. of the $21^{\text {th }}$ Ann. Conf. of the Int'l Group for Lean Construction. Fortaleza, Brazil. 
Murali Jagannathan, Ravindranadh Chowdary Kamma, Venkatesan Renganaidu,

Shobha Ramalingam

Huovila, P., and Koskela, L. (1998, August). "Contribution of the principles of lean construction to meet the challenges of sustainable development." Proc. of the $6^{\text {th }}$ Ann. Conf. of the Int'l Group for Lean Construction.Guaruja, Brazil.

Indian Express (2014). "Mandatory 2\% CSR spend set to kick in from April 1." Newspaper article (Dec. 12, 2017).

Jamil, A. H. A., and Fathi, M. S. (2016). "The integration of lean construction and sustainable construction: A stakeholder perspective in analyzing sustainable lean construction strategies in Malaysia." Procedia Computer Science, 100, 634-643.

Jha, K. N., and Iyer, K. C. (2006). "Critical factors affecting quality performance in construction projects." Total Quality Management and Business Excellence, 17(9), 1155-1170.

Johnsen, C. A., and Drevland, F. (2016). "Lean and Sustainability: three pillar thinking in the production process." Proc. of the $24^{\text {th }}$ Ann. Conf. of the Int'l Group for Lean Construction. Boston, USA.

Kardos, M. (2012). "The reflection of good governance in sustainable development strategies." Procedia-Social and Behavioral Sciences, 58, 1166-1173.

Kocmanová, A., Hřebíček, J., \& Dočekalová, M. (2011). "Corporate Governance And Sustainability." Economics \& Management, 16.

Koskela, L. (1992). "Application of the new production philosophy to construction." Center for Integrated Facility Engineering, 1-81.

Kumar., Kishore, D., and Prabhakaran, L. (2017). "BIM 360 Pilot at L\&T Construction."Proc., of the Indian Lean Construction Conference, Chennai, India, C62 - C67.

Lad, J., Sudheer, N.A., Rao, D.P.G., and Patwardhan, S. (2017). “Applying Lean Tools to Reduce Piling Cycle Time for a Marine Infrastructure Project in Western India."Proc., of the Indian Lean Construction Conference, Chennai, India, C186 C194.

Lahoti, T., and Rathore, G.S. (2017). "Last Planner System at Godrej Construction."Proc., of the Indian Lean Construction Conference, Chennai, India, C195 - C201.

Lapinski, A. R., Horman, M. J., and Riley, D. R. (2006). "Lean processes for sustainable project delivery." Journal of construction engineering and management, 10.1061/(ASCE)0733-9364(2006)132:10(1083).

Liang, S. Y., Putuhena, F. J., Ling, L. P. and Baharun, A. (2014), "Towards implementation and achievement of construction and environmental quality in the Malaysian construction industry."Malaysian Journal of Civil Engineering, 26 (1), 99114.

Loganathan, S., and Kalidindi, S. N. (2016). "Absenteeism and Turnover of Migrant Construction Workers in Indian Projects?A Survey-Based Study." Construction Research Congress 2016, Proceedings, 1793-1802.

Loganathan, S and Kalidindi, N.S. (2017). "Labour Sub-Contracting Issues in the Indian Construction Industry."PMI Research and Academic Conference 2017, Indian Institute of Technology Madras. 
Marhani, M. A., Jaapar, A., Bari, N. A. A., and Zawawi, M. (2013). "Sustainability through lean construction approach: A literature review." Procedia-Social and Behavioral Sciences, 101, 90-99.

Mathew, Anup. (July, 2017). "Lean implementation at Godrej construction."Proc., of the Indian Lean Construction Conference, Chennai, India, A20-A35.

Mukherjee, D., and Ghosh, T. (2004). "An analysis of corporate performance and governance in India: Study of some selected industries." Indian Statistical Institute. Kolkata. India.

Murthy, S.R.S., Awadhiya, R., Prasanna, S.K., and Danthi, C. (2017). "Lean Applications in EOHT Construction."Proc., of the Indian Lean Construction Conference, Chennai, India, C323 - C330.

Negi, M, Ahuja, V and Baruah, P. (2017). "Sustainable Supply Chain Management in Indian Construction Industry."In: National Conference on Sustainable Supply Chain Management - An Indian Perspective, Centre for Research in Materials Management, Kolkata, India.

Novak, V. M. (2012). "Value paradigm: revealing synergy between lean and sustainability." Proc. of the $20^{\text {th }}$ Ann. Conf. of the Int'l Group for Lean Construction.San Diego, USA.

OECD Principles. (2004). "OECD Principles of Corporate Governance." OECD Publications Service, 1-178.

Ogunbiyi, O., Goulding, J. S., and Oladapo, A. (2014). "An empirical study of the impact of lean construction techniques on sustainable construction in the UK." Construction Innovation, 14(1), 88-107.

Pande, S., and Kaushik, K. V. (2012). "Study on the state of corporate governance in India-evolution, issues and challenges for the future." Indian Institute of Corporate Affairs.

Patel, D. A., and Jha, K. N. (2016). "An Estimate of Fatal Accidents in Indian Construction." Proceedings of the 32nd Annual ARCOM Conference, 1(September), 577-586.

Patil, P., Jayarajan, S., and Joshi, H. (2017). "Respect for People: Transforming the Way We Work."Proc., of the Indian Lean Construction Conference, Chennai, India, C251 $-\mathrm{C} 256$.

Piercy, N., and Brammer, S. (2012). "A complete definition of corporate social responsibility and sustainability." British Academy Report.

Piercy, N., and Rich, N. (2015). "The relationship between lean operations and sustainable operations." International Journal of Operations \& Production Management, 35(2), 282-315.

Planning Commission (2013). Twelfth Five Year Plan (2012-2017). Planning Commission, Government of India, SAGE Publications India Pvt. Ltd.

Potdar, J., Khare, V., Lahori, Y., and Kamble, K. (2017). "Collaborating to Create Value: Implementing Lean Construction at Godrej Infinity, Pune."Proc., of the Indian Lean Construction Conference, Chennai, India, C99 - C106.

Raghavan, N. (2017). "Lean - The Many Splendoured Thing."Proc., of the Indian Lean Construction Conference, Chennai, India, B4-B10. 
Murali Jagannathan, Ravindranadh Chowdary Kamma, Venkatesan Renganaidu,

Shobha Ramalingam

Saggin, A. B., Valente, C. P., Mourao, C. A. M. A., and Cabral, A. E. B. (2015, July). "Comparing investments in sustainability with cost reduction from waste due to lean construction." Proc. of the $23^{\text {rd }}$ Ann. Conf. of the Int'l Group for Lean Construction.Perth, Australia.

Salem, O., Pirzadeh, S., Ghorai, S., and Abdel-Rahim, A. (2014). "Reducing environmental, economic, and social impacts of work-zones by implementing Lean Construction techniques." Proc. of the $22^{\text {nd }}$ Ann. Conf. of the Int'l Group for Lean Construction. Oslo, Norway.

Salvatierra-Garrido, J., and Pasquire, C. (2011)."The First and Last Value Model: Sustainability as a First Value Delivery of Lean Construction Practice."Proc. of the $19^{\text {th }}$ Ann. Conf. of the Int'l Group for Lean Construction.Lima, Peru.

Shen, L., Yao, H., Alan, G. (2006). "Improving environmental performance by means of empowerment of contractors."Management of Environmental Quality: An International Journal, 17 (3), 242-257.

Tan, Y., Shen, L. and Yao, H. (2011)."Sustainable construction practice and contractor's competitiveness: a preliminary study."Habitat International, 35 (2), 225-230.

Vaidyanathan, K., Mohanbabu, S., Sriram, P., Rahman, S., and Arunkumar, S. (2016). "Application of lean principles to managing construction of an IT commercial facility - an Indian experience."Proc. of the $24^{\text {th }}$ Ann. Conf. of the Int'l Group for Lean Construction.Boston, USA.

Vieira, A., and Cachadinha, N. (2011). "Lean construction and sustainabilitycomplementary paradigms-a case study."Proc. of the $20^{\text {th }}$ Ann. Conf. of the Int'l Group for Lean Construction.Lima, Peru.

WCED (World Commission on Environment and Development) (1987). Our common future Oxford University Press, Oxford. 